\title{
Árido siderúrgico en hormigones: proceso de envejecimiento y su efecto en compuestos potencialmente expansivos
}

\section{Steel slag aggregate in concrete: the effect of ageing on potentially expansive compounds}

\author{
M. Frías $^{(*)}$, J. T. San-José(**) (***), I. Vegas ${ }^{(* * *)}$
}

Recepción/Received: 30-XI-07

Aceptación/Accepted: 3-IV-08

Publicado online/Online publishing: 12-II-10

\section{RESUMEN}

En los últimos años están surgiendo diferentes plantas de tratamiento de las escorias generadas en el proceso de fusión de la chatarra en los hornos de arco eléctrico. Mediante procesos de separación, machaqueo y cribado se obtiene un material granular denominado árido siderúrgico, que puede ser atractivo para su utilización en la fabricación de hormigones comerciales. En este sentido, la viabilidad de dicha aplicación dependerá, fundamentalmente, de asegurar su estabilidad en volumen.

Este trabajo presenta un estudio de los compuestos potencialmente expansivos ( $\mathrm{Cl}^{-}, \mathrm{SO}_{3}, \mathrm{CaO}$ libre y $\mathrm{MgO}$ libre) de los áridos siderúrgicos procedentes de diferentes tipos de escorias negras, así como su evolución después de un proceso de envejecimiento. El objetivo es establecer las condiciones óptimas de un proceso de envejecimiento a partir del cual se pueda asegurar la estabilidad, en volumen, del árido siderúrgico. Los resultados evidencian que las escorias analizadas tienen bajas concentraciones de los compuestos expansivos analizados y que el proceso de envejecimiento puede reducir la posible inestabilidad de volumen después de 45 días de tratamiento.

Palabras clave: escorias, áridos, hormigón, compuestos expansivos.

\section{SUMMARY}

Growing numbers of plants have sprung up in recent years to treat the electric arc furnace slag generated in scrap metal melting. When this by-product is separated, crushed and screened, it yields a granular material known as steel slag aggregate, which may be profitably used in the manufacture of commercial concrete. The feasibility of this application depends essentially on the volume stability of the resulting aggregate.

The present paper discusses the potentially expansive compounds ( $\mathrm{Cl}, \mathrm{SO}_{3}$, free $\mathrm{CaO}$ and free $\mathrm{MgO}$ ) present in aggregate derived from different types of black slag during aggregate ageing. The aim is to establish optimal ageing conditions to ensure volume stability in steel slag aggregate. The findings showed that the slag analyzed had low concentrations of the expansive compounds studied and that possible swelling can be reduced by $45-$ day ageing.

Keywords: slag, aggregate, concrete, expansive compounds.

(*) Instituto Eduardo Torroja (CSIC) (Madrid, España).

(**) Universidad del País Vasco (UPV/EHU) (Bilbao, España).

(***) Labein-Tecnalia (Derio, España). 


\section{INTRODUCCIÓN}

El reciclado y valorización de subproductos y residuos industriales pasa por llevar a cabo estudios de caracterización dirigidos a establecer aplicaciones concretas en función de sus características (1-4). La fabricación de aceros genera grandes volúmenes de escorias, cuyas características químicas y mineralógicas son bien conocidas y, por ello, han podido reciclarse en diferentes procesos industriales. Las escorias de alto horno por sus propiedades hidráulicas resultan muy atractivas para la industria del cemento (fabricación de CEM III). De acuerdo con los datos disponibles en Europa se generaron, aproximadamente, 25 millones de toneladas de escoria de alto horno durante el año 2000 (5).

Las escorias obtenidas del proceso de fusión de la chatarra (escoria negra) en horno eléctrico de arco (HEA) presentan, también, un importante potencial en aplicaciones constructivas. Sometidas a procesos de separación, machaqueo y cribado, se obtiene un material granular (árido siderúrgico) con un amplio potencial de utilización en aplicaciones constructivas.

Además de su aplicación en carreteras (6-13) y como una alternativa más de uso, el árido siderúrgico resulta de interés en la fabricación de hormigones $(14,15)$.

En un trabajo previo, Frías y Col. (16) indicaban que las escorias negras de HEA no manifiestan actividad puzolánica. Por lo tanto, éstas no pueden utilizarse como adiciones activas en la fabricación de cementos comerciales. Posteriormente los mismos autores (17) centraron las investigaciones en evaluar el potencial del árido siderúrgico procedente de la escoria. Después de analizar dos tipos de escoria negra con origen diferente, se puso de manifiesto que dicho material no desarrollaba inestabilidades apreciables de volumen debido a compuestos potencialmente expansivos. En cualquier caso, se antoja necesario profundizar sobre la influencia de determinados compuestos de la escoria negra en la estabilidad del producto final.

En respuesta a esta necesidad, el presente artículo recoge la metodología y resultados de un trabajo experimental dirigido a analizar la evolución de los contenidos de compuestos e iones potencialmente expansivos (cloruros, sulfatos, cal y magnesia libre, y óxido de hierro) de escorias de diferente procedencia, durante un determinado proceso de envejecimiento.

\section{PARTE EXPERIMENTAL}

\subsection{Materiales}

Se seleccionaron dos escorias de horno de arco eléctrico (EHAE1 y EHAE2) de diferentes acerías españolas. Se tamizaron para obtener diferentes intervalos granulométricos,

\section{INTRODUCTION}

Industrial by-products and wastes are only recyclable or reusable after characterization studies have been conducted to establish specific applications in keeping with the properties of these substances (1-4). The enormous volumes of slag generated by steel manufacture can be recycled in a number of industrial processes because slag chemical and mineralogical characteristics are well known. The hydraulic properties of blast furnace slag, for instance, have attracted the attention of the cement industry (manufacture of CEM III). According to the data available, approximately 25 million tonnes of blast furnace slag were generated in Europe in 2000 (5).

The black slag obtained from scrap metal melted in electric arc furnaces (EAF), when separated, crushed and screened to yield a granular material known as steel slag aggregate, also holds substantial promise for use in construction.

In addition to its use in roads (6-13), steel slag aggregate may be apt for concrete manufacture $(14,15)$.

In a prior paper, Frías et al. (16) reported that EAF black slag exhibited no pozzolanic activity. Consequently, it cannot be used as an active addition in commercial cement manufacture. Subsequently, the same authors (17) evaluated the potential of aggregate deriving from steel mill slag. After analyzing two types of black slag, they found that the material underwent no perceptible swelling due to the presence of potentially expansive compounds. Nonetheless, further study is required on the effect of certain components of black slag on end product stability.

In response to this need, the present experimental study analyzed the ageing-induced variation in the content of potentially expansive compounds and ions (chlorides, sulphates, free lime and magnesium, and iron oxide) in slag of different origins.

\section{EXPERIMENTAL}

\subsection{Materials}

Two types of electric arc furnace slag (EAFS1 and EAFS2) were selected, each from a different Spanish steel mill. They were sieved to obtain the different 
que estaban relacionados con las fracciones granulométricas empleadas habitualmente en la fabricación de hormigones tradicionales. Cada fracción fue molida y tamizada por debajo de $100 \mu \mathrm{m}$.

La composición química (FRX) y mineralógica (DRX) de ambas escorias, para cada intervalo granulométrico, se recogen en las Figuras 1 y 2, respectivamente. Son escorias cualitativamente similares con diferencias cuantitativas en los contenidos de cal, sílice, alúmina y magnesia. No se observa una influencia directa de los intervalos granulométricos en los contenidos de los óxidos. Mineralógicamente, las escorias seleccionadas están formadas por compuestos bien cristalizados, detectándose la presencia de w/plustita (W, FeO), magnesioferrita/magnetita $\left(\mathrm{M}, \mathrm{MgFe}_{2} \mathrm{O}_{4} / \mathrm{Fe}_{3} \mathrm{O}_{4}\right)$, hematite $\left(\mathrm{H}, \mathrm{Fe}_{2} \mathrm{O}_{3}\right)$, larnita $\left(\mathrm{L}, \mathrm{Ca}_{2} \mathrm{SiO}_{4}\right)$, bridigita/merwinita (B $\left.\left.(\mathrm{Ca}, \mathrm{Fe}, \mathrm{Mg})_{2} \mathrm{SiO}_{4}\right) / \mathrm{Ca}_{3} \mathrm{Mg}\left(\mathrm{SiO}_{4}\right)_{2}\right)$, gehlenita $\left(\mathrm{G}, \mathrm{Ca}_{2} \mathrm{Al}_{2} \mathrm{SiO}_{7}\right)$ y óxidos de manganeso $\left(\mathrm{Mn}, \mathrm{MnO}_{2}\right)$. granulometric intervals ordinarily used in the manufacture of conventional concrete. Each fraction was subsequently ground and sieved to under $100 \mu \mathrm{m}$.

Slag chemical (XRF) and mineralogical (XRD) composition, found for each particle size interval, is shown in Figures 1 and 2, respectively. Qualitatively, the two types of slag were similar, with quantitative differences in lime, silica, alumina and magnesia contents. The particle size intervals were not observed to have any direct effect on the oxide content. The slag selected contained well crystallized minerals, including W/piustite $(\mathrm{W}, \mathrm{FeO})$, magnesium ferrite/magnetite ( $\mathrm{M}$, $\left.\mathrm{MgFe}_{2} \mathrm{O}_{4} / \mathrm{Fe}_{3} \mathrm{O}_{4}\right)$, hematite $\left(\mathrm{H}, \mathrm{Fe}_{2} \mathrm{O}_{3}\right)$, larnite $(L$, $\left.\mathrm{Ca}_{2} \mathrm{SiO}_{4}\right)$, bredigite/merwinite (B $(\mathrm{Ca}, \mathrm{Fe}, \mathrm{Mg}) / \mathrm{Ca}_{3} \mathrm{Mg}$ $\left.\left(\mathrm{SiO}_{4}\right)_{2}\right)$, gehlenite $\left(\mathrm{G}, \mathrm{Ca}_{2} \mathrm{Al}_{2} \mathrm{SiO}_{7}\right)$ and manganese oxides ( $\mathrm{Mn}, \mathrm{MnO}_{2}$ ).

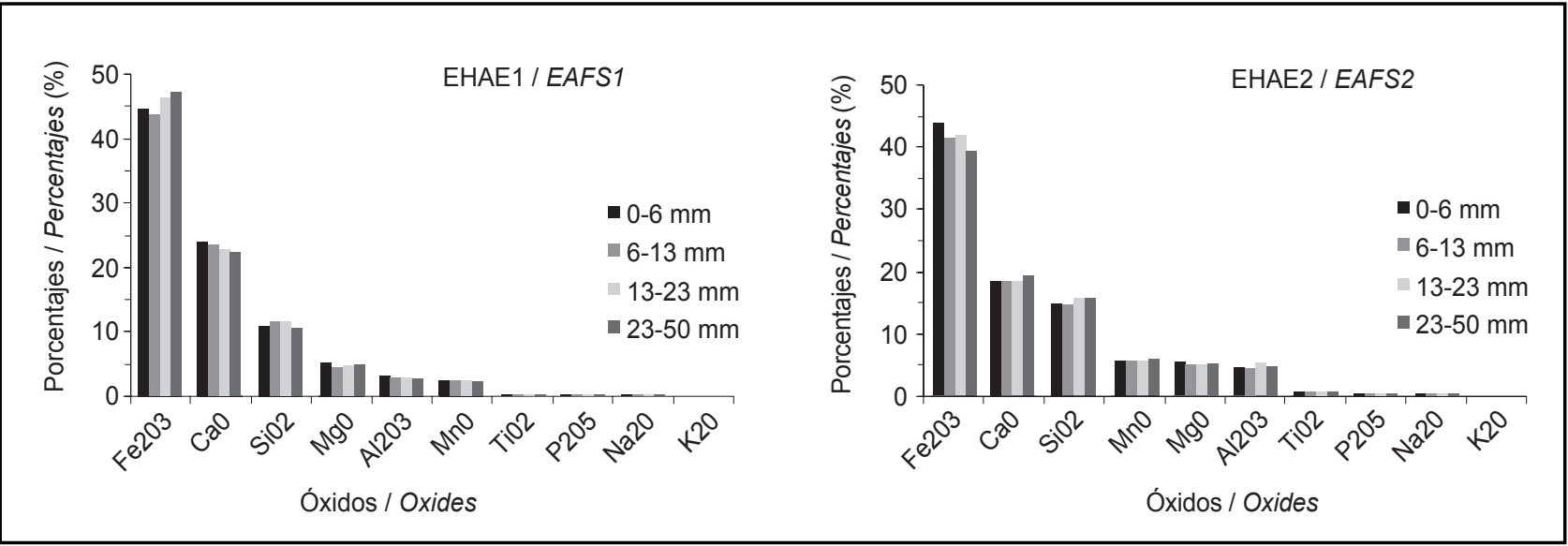

Figura 1. Variaciones de la composición química de las escorias en función del intervalo granulométrico.

Figure 1. Variation in the chemical composition of slag with particle size interval.

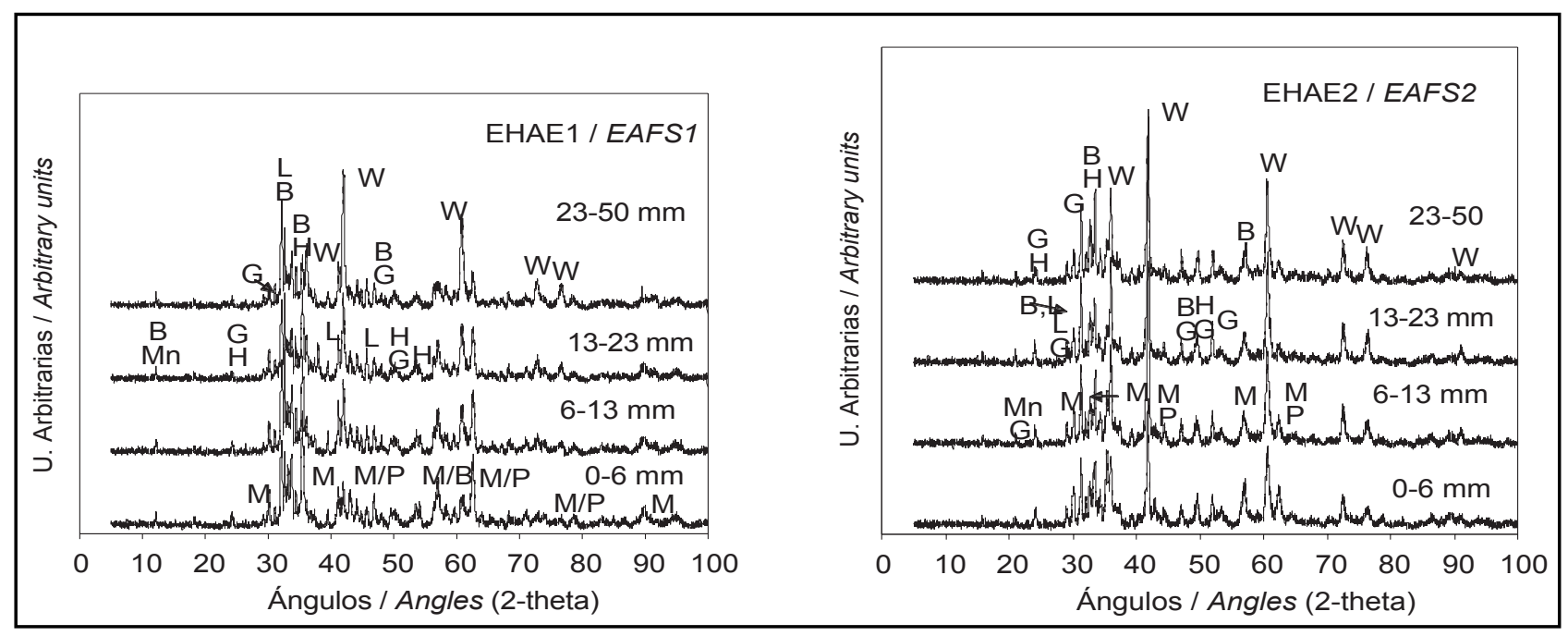

Figura 2. Difractogramas de DRX de las escorias EHAE1 y EHAE2 en función del intervalo granulométrico.

Figure 2. XRD traces for slag EAFS1 and EAFS2 by particle size interval. 


\subsection{Metodología}

La metodología empleada para la determinación cuantitativa de los compuestos expansivos (cloruros, sulfatos, cal libre y óxidos de hierro) presentes en las escorias negras ha sido la descrita en la norma española vigente (18). En la actualidad, no existe ninguna normativa para la cuantificación de la magnesia libre y las consultadas sólo limitan el contenido de óxido de magnesio total, para limitar posibles fenómenos expansivos debido a la presencia de magnesia libre, en forma de periclasa, la posterior hidratación de la misma es la causante de procesos de deterioro a medio y largo plazo. Como una primera aproximación para poder cuantificar este compuesto expansivo en las escorias negras, los autores han tomado como punto de partida la metodología sugerida por Taylor and Bogue (19), la cual se basa en cuantificar el MgO libre, lixiviado, de un material de clínker en una solución no acuosa de nitrato amónico en alcohol y glicerol.

\section{RESULTADOS Y DISCUSIÓN}

La Instrucción Española de Hormigón Estructural-EHE (20) define que "como áridos para la fabricación de hormigones pueden emplearse arenas y gravas existentes en yacimientos naturales, rocas machacadas o escorias siderúrgicas apropiadas, así como otros productos, cuyo empleo se encuentre sancionado por la práctica o resulte aconsejable como consecuencia de estudios realizados en laboratorio".

De acuerdo con esta definición, los áridos siderúrgicos procedentes de la escoria negra EHAE podrían utilizarse como material granular en la fabricación de hormigones, siempre y cuando cumplan, como mínimo, con las especificaciones y limitaciones recogidas en dicha Instrucción (17).

\subsection{Compuestos potencialmente expansivos presentes en las escorias de partida}

La Figura 3 recoge las variaciones de concentraciones máxima y mínima para los diferentes compuestos expansivos detectados en las dos escorias. Los contenidos de cal libre, valores $\leq 0,1 \%$, son muy bajos en todos los casos analizados. Los compuestos de azufre total, expresado como $\mathrm{SO}_{3}$, no alcanzaban el $0,6 \%$, valores muy inferiores al especificado en la Instrucción EHE (máximo permitido $1 \%$ expresado como S). Como estos valores también estarían por debajo del contenido máximo de sulfatos solubles $(\leq 0,8 \%)$, por lo que no fue necesario su cuantificación según la metodología descrita.

En las escorias de acería no se detectó la presencia de cloruros, aspecto importante a la hora de fabricar hormigones armados y pretensados.

\subsection{Methodology}

The methodology stipulated in the existing Spanish legislation (18) was used to quantify the expansive compounds (chlorides, sulfates, free lime and iron oxides) present in black slag. No legislation is presently in place to quantify free magnesia.. In the standards consulted, possible expansion due to the presence of free magnesia in the form of periclase (whose hydration occasions medium- and long-term deterioration) is restrained by limiting the total magnesium oxide content only. Consequently, the free magnesia content was roughly estimated here using the procedure suggested by Taylor and Bogue (19), which consists in quantifying the free $\mathrm{MgO}$ leached out of clinker into a non-aqueous solution of ammonium nitrate in alcohol and glycerol.

\section{RESULTS AND DISCUSSION}

The existing Spanish structural concrete code (EHE) (20) provides that "sand and gravel from natural deposits, crushed stone or suitable steel mill slag, and other products endorsed by practice or found to be recommendable on the grounds of laboratory testing, may be used as an aggregate for concrete manufacture".

Pursuant to this definition, EAF steel slag aggregate may be used as granular material to manufacture concrete, providing it complies with the specifications and limitations laid down in the EHE code (17).

\subsection{Potentially expansive compounds present in the starting materials}

Figure 3 shows the maximum and minimum concentrations of the expansive compounds detected in the two types of slag. The free lime content, with values of $\leq 0.1 \%$, was consistently low in all the cases analyzed. The total sulfur content, expressed as $\mathrm{SO}_{3}$, was under $0.6 \%$, i.e., much lower than specified in the concrete code (which allows a maximum of $1 \%$ expressed as $S$ ). Inasmuch as these values were also lower than the maximum allowable soluble sulfate content $(\leq 0.8 \%)$, quantification of the latter as stipulated in the code was regarded to be unnecessary.

No chlorides were detected in the steel mill slag, a finding that is particularly relevant in the context of reinforced and prestressed concrete manufacture. 


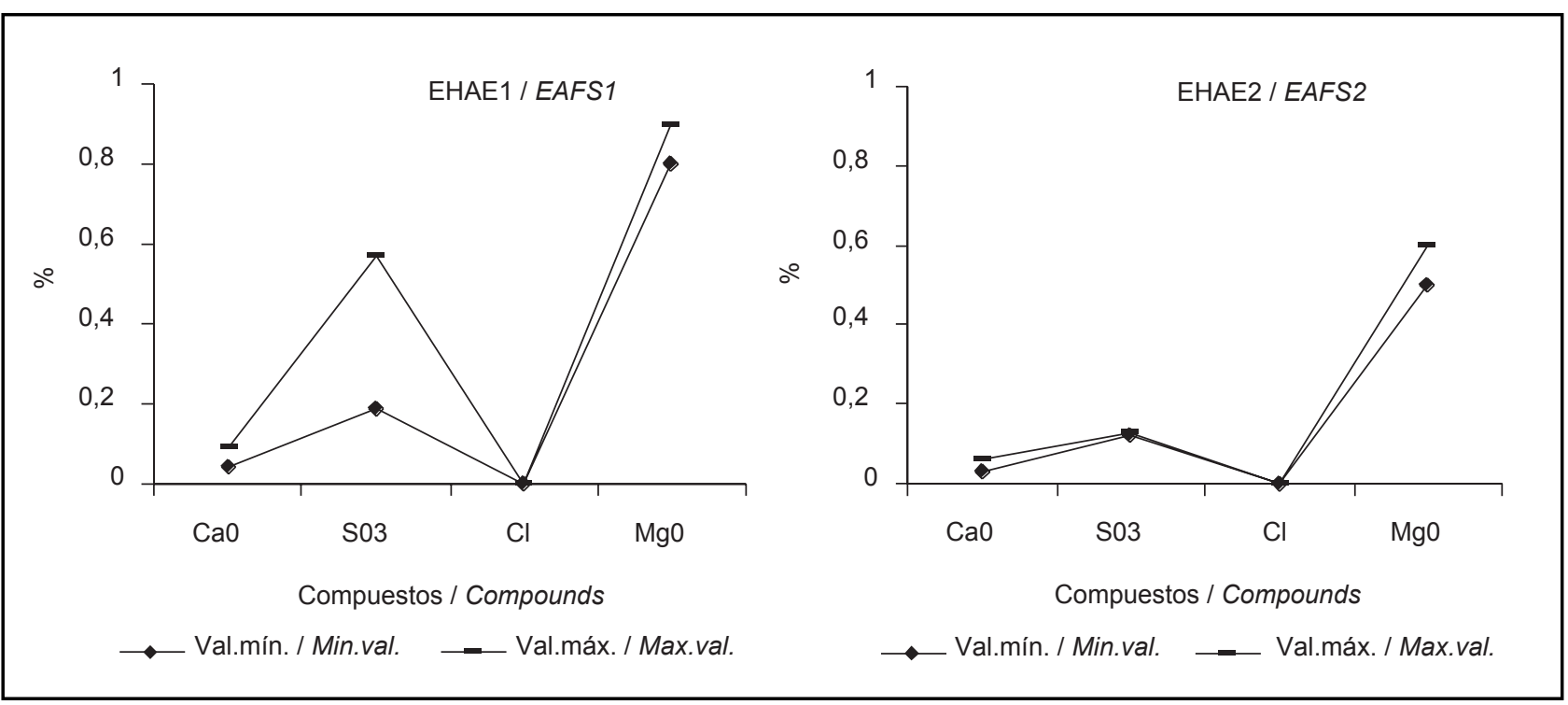

Figura 3. Evolución de los compuestos expansivos en las dos escorias.

Figure 3. Maximum and minimum percentages of the expansive compounds in two types of slag.

En todos los casos analizados, los valores encontrados para la cal libre, sulfatos y cloruros son muy similares en ambas escorias por lo que no se detecta una influencia directa entre los intervalos granulométricos y la concentración de estos compuestos expansivos, a excepción de la escoria EHAE1, cuyo contenido en sulfatos ( $\mathrm{como} \mathrm{SO}_{3}$ ) disminuye con el incremento del tamaño de partícula. Dichos contenidos oscilan desde $0,57 \%$ en el intervalo granulométrico de $0-6 \mathrm{~mm}$ hasta $0,19 \%$ en el intervalo entre $23-50 \mathrm{~mm}$.

Como se ha comentado anteriormente, uno de los compuestos con mayor influencia negativa en la durabilidad de las matrices de cemento es el óxido de magnesio libre; especialmente, cuando está en forma de periclasa. Este compuesto reacciona lentamente con el agua para formar hidróxido de magnesio (brucita). Esta transformación lleva asociada un incremento importante de volumen, provocando la degradación de la matriz a medio y largo plazo. La presencia de este compuesto puede limitar el uso del árido siderúrgico en la fabricación de hormigones.

El contenido de $\mathrm{MgO}$ varía ligeramente en función de la procedencia de la escoria. Para el caso de la escoria EAHE1 se han encontrados valores entre 0,5 y $0,6 \%$ de $\mathrm{MgO}$ libre y entre 0,8 y $0,9 \%$ para la escoria designada como EAHE2 (Figura 3). Estos valores son muy similares para cada escoria analizada, no presentando ninguna variación con el intervalo granulométrico. Estos datos estarían de acuerdo con los obtenidos por difracción de rayos X (Figura 4) donde no se detecta la presencia de este compuesto cristalino (periclasa) (21).
In all the cases analyzed, the free lime, sulfate and chloride values found were similar in the two types of slag. Consequently, the particle size intervals had no direct effect on the concentration of these expansive compounds, except in slag EAFS1 whose sulfate $\left(\mathrm{SO}_{3}\right)$ content declined with particle size. The values observed ranged from $0.57 \%$ in the $0-6-\mathrm{mm}$ interval to $0.19 \%$ in the 23-50-mm interval.

As noted earlier, one of the most compounds that affects cement matrix durability most adversely is free magnesium oxide, particularly in the form of periclase, which reacts slowly with water to form magnesium hydroxide (brucite). This transformation involves a substantial increase in volume, and consequently matrix degeneration in the medium and long term. The presence of this compound may limit the use of steel slag aggregate in concrete manufacture.

The MgO content varied slightly depending on slag origin. Slag EAFS1 was found to contain from 0.5 to $0.6 \%$ of free $M g O$, whereas in slag EAFS2 the percentage ranged from 0.8 to $0.9 \%$ (Figure 3 ). These values, which were not observed to vary with the particle size interval, were consistent with the $X$-ray diffraction findings (Figure 4), in which no periclase was detected (21). 


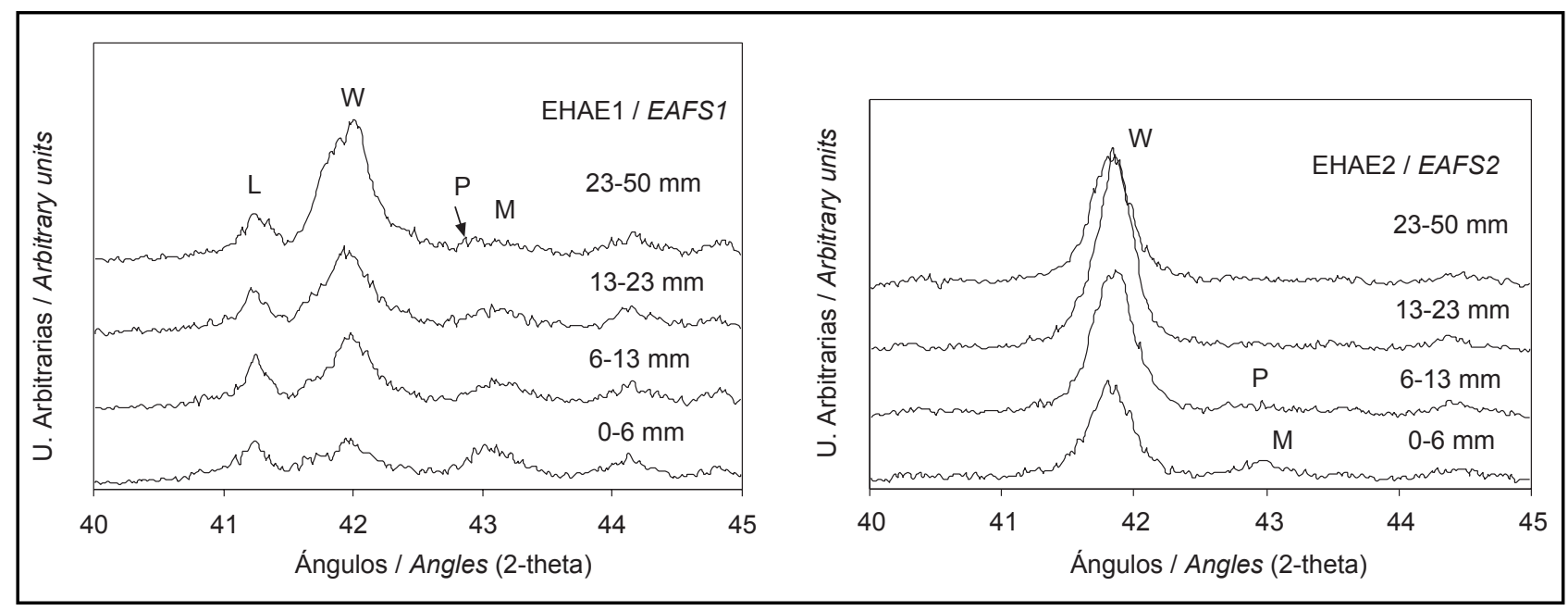

Figura 4. Difractogramas de DRX de las escorias EHAE1 y EHAE2 en el intervalo $40^{\circ}-45^{\circ}(21)$ y para diferentes intervalos granulométricos. Figure 4. XRD traces for slag EAFS1 and EAFS2 in the 40-450 (21) range by particle size interval.

A pesar de estos buenos resultados analíticos obtenidos de la muestra después de su trituración, molienda y homogeneización de la escoria para su posterior análisis, la observación visual detallada de las propias partículas de escorias antes de este proceso, pone de relieve que, esporádicamente, en alguna escoria de acería podría aparecer incrustaciones de color blanco entre las partículas de las escorias, como ocurría en una de las escorias estudiadas en el presente trabajo (Figura 5). Estas incrustaciones aisladas fueron analizadas por DRX identificándose la presencia de $\mathrm{MgO}$ cristalizado (periclasa) como compuesto principal (Figura 6). El análisis químico llevado a cabo en estas partículas mostraba concentraciones importantes de $\mathrm{MgO}$ libre (4,5\%). Este hecho pone de manifiesto que si se utiliza esta escoria como árido de reciclado, la aparición de estas incrustaciones pueden ser puntos problemáticos desde el punto de vista de la durabilidad. Sin embargo, una vez procesadas (trituración, molienda, homogeneización, etc.) para su caracterización analítica, éstas se diluyen en su conjunto y no son claramente identificadas por DRX.

A pesar de que ambas escorias presentan contenidos analíticos muy bajos de compuestos potencialmente expansivos (sulfatos, cloruros, cal libre y magnesia libre), las escorias fueron sometidas a un ensayo acelerado según la norma ASTM (22). La Figura 7 muestra la evolución de los datos de expansión para las dos escorias analizadas, incluyendo también la función logarítmica asociada a su evolución. De acuerdo con los datos obtenidos se confirma, de nuevo, que las dos escorias presentaban una baja inestabilidad de volumen $(0,20$ $0,25 \%)$, valores inferiores al $0,5 \%$ especificado en la norma americana (23). Como se observa, la escoria EHAE2 presenta un valor menor que la escoria EHAE1, fenómeno achacable a un menor contenido en sulfatos y magnesia libre.
Despite these good analytical results after crushing, grinding and homogenizing the slag sample, a careful visual inspection of the slag particles prior to that process revealed the sporadic presence of white incrustations among the particles in one of the types of slag studied Figure 5). When analyzed with XRD, these incrustations were found to contain crystallized $\mathrm{MgO}$ (periclase) as their main component (Figure 6). Moreover, the chemical analysis showed that they contained significant concentrations of free $\mathrm{MgO}$ (4.5\%). Further to this finding, the appearance of such incrustations could pose durability problems if this slag were to be used as recycled aggregate. After processing (crushing, grinding, homogenizing and so on) for analytical characterization, however, these incrustations were diluted in the overall mass and not clearly identifiable on the XRD traces.

Even though the two types of slag contained very small amounts of potentially expansive compounds (sulfates, chlorides, free lime and magnesium), accelerated ageing tests were conducted on both to ASTM specifications (22). Figure 7 shows the variation in the expansion data for the slag analyzed, along with the associated logarithmic function. The findings confirmed that the minor swelling taking place in both types of slag (0.20$0.25 \%$ ) was under the $0.5 \%$ ceiling specified in the American standard (23). The value for slag EAFS2 was smaller than for slag EAFS1, a finding attributable to the lower sulfate and free magnesia content in the former. 


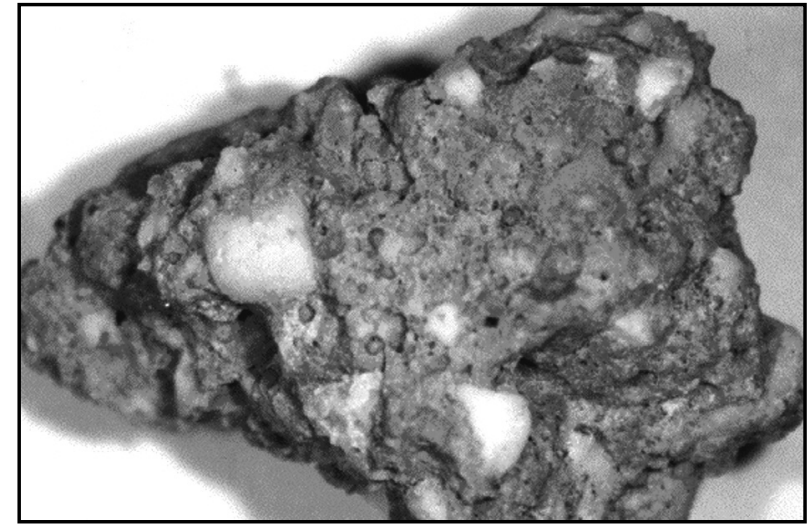

Figura 5. Aspecto de la partícula de escoria con alto contenido en periclasa obtenida por lupa $(1 \times 2,5)$. Figure 5. Slag particle with high periclase content, under $1 \times 2.5$ magnification.

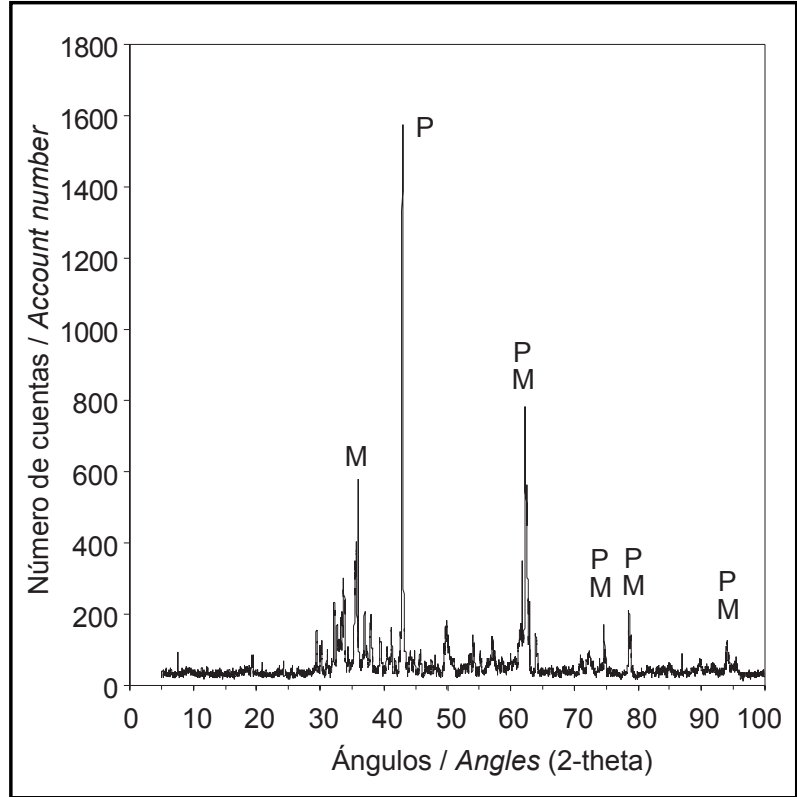

Figura 6. Difractograma de DRX de la partículas de periclasa.

Figure 6. XRD diffractogram for periclase particles.

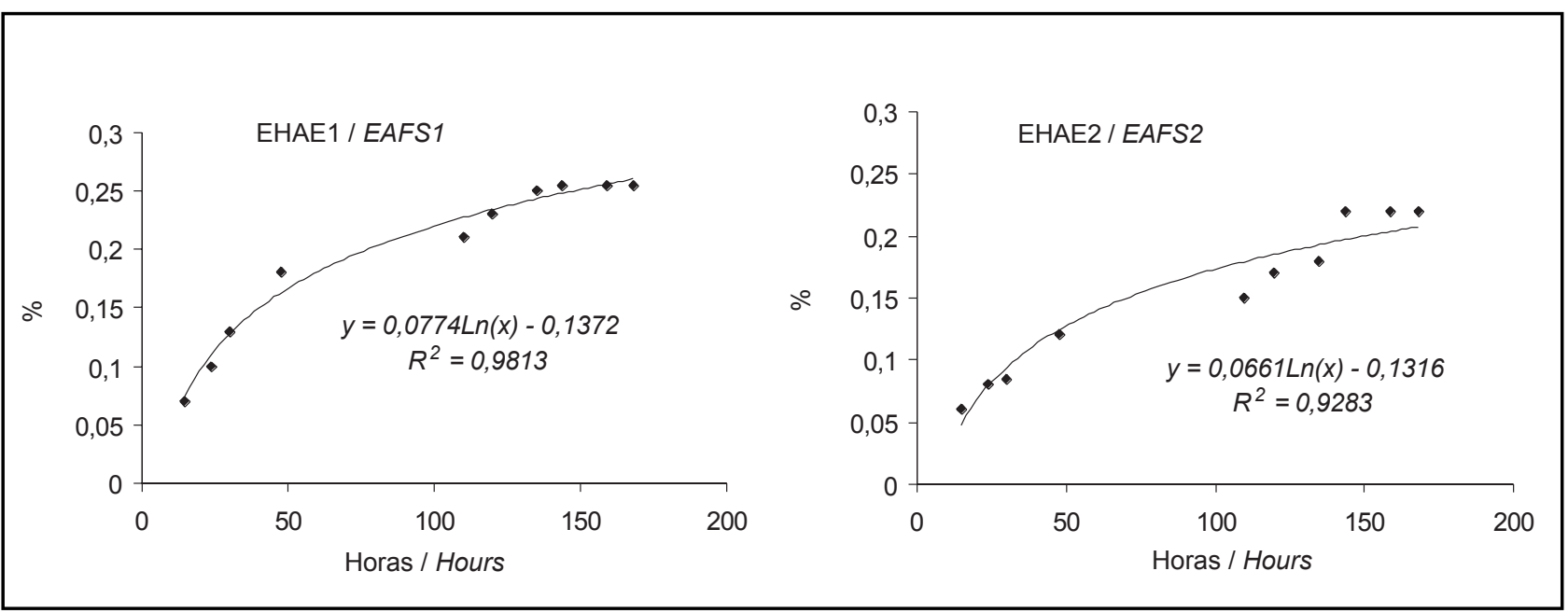

Figura 7. Evolución de la expansión de las escorias.

Figure 7. Slag expansion versus time.

\subsection{Evolución de los compuestos expansivos después de un proceso de envejecimiento}

El envejecimiento habitual dado a la escoria negra para asegurar la estabilidad en volumen se caracteriza por extender el material en una superficie amplia y someterlo a ciclos de humectación-secado (24). Para este trabajo se envejeció la escoria entre 45 y 90 días con la finalidad de limitar los efectos expansivos (cal libre, magnesia libre, pérdida por oxidación) antes de obtener el árido siderúrgico para fabricar hormigón.

\subsection{Variation in the expansive compounds after ageing}

The normal ageing performed on black slag to ensure volume stability consists in exposing the material, spread over a flat surface, to wet-dry cycles (24). In the present study, the slag was aged for 45 and 90 days to limit expansion (free lime, free magnesia, loss on oxidation) prior to producing steel slag aggregate for making concrete. 


\subsubsection{Aspecto de las escorias envejecidas}

Una vez envejecidas las escorias, después de 90 días de tratamiento, se observó un cambio de color en sus partículas. La observación, detallada, por medio de una lupa binocular (Figura 8) detectó que dichas partículas están envueltas de una capa fina blanquecina. El estudio por espectroscopía infrarroja, de este producto obtenido con una espátula de la superficie de la partícula, revela la presencia de bandas de absorción $\mathrm{C}-\mathrm{O}$ a frecuencias de $1.428,875$ y $710 \mathrm{~cm}^{-1}$, las cuales corresponden a la presencia de carbonatos cálci$\cos$ y, en concreto, a calcita (Figura 9), corroborando los datos de DRX. Otros posibles carbonatos y sulfatos, como consecuencia de la lixiviación durante el proceso de envejecimiento (dolomita, sulfato cálcico, etc.) no son identificados por IR.

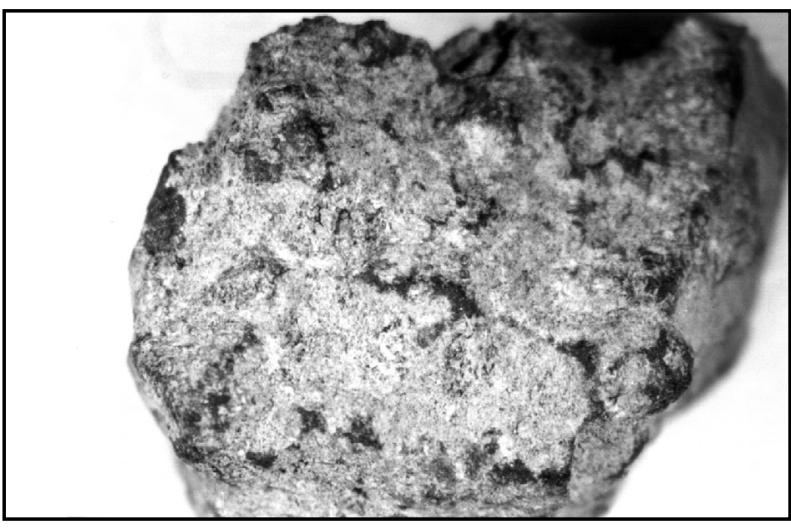

Figura 8. Aspecto de la escoria tratada obtenida por lupa $(1 \times 2,5)$. Figure 8. Treated slag, under $1 \times 2.5$ magnification.

La aparición de este producto de reacción puede relacionarse con fenómenos asociados a procesos de envejecimiento:

1. Los compuestos solubles de las escorias se disuelven durante el proceso de humedad, precipitando, posteriormente, en la superficie de las partículas durante el proceso de secado.

2. Una vez en la superficie, la acción del $\mathrm{CO}_{2}$ atmosférico reacciona con el precipitado para formar principalmente carbonatos cálcicos en forma de calcita, como se comenta en el apartado siguiente.

\subsubsection{Evolución de los compuestos mineralógicos}

Para ver la influencia del proceso de envejecimiento en las escorias seleccionadas se ha llevado a cabo un estudio por DRX, en cada una de las fracciones granulométricas. Las Figuras 10 y 11 ilustran los difractogramas

\subsubsection{Appearance of aged slag}

After 90 days, particle colour was observed to change in the aged slag. Careful observation under a binocular microscope (Figure 8) showed that the particles were wrapped in a thin whitish film. Infrared spectroscopic studies of the product obtained by scraping the particle surface with a spatula revealed the presence of $\mathrm{C}-\mathrm{O}$ absorption bands at frequencies of 1428, 875 and 710 $\mathrm{cm}^{-1}$, indicating the presence of calcium carbonates, specifically calcite (Figure 9), and corroborating the XRD findings. Since other carbonates and sulfates such as dolomite, calcium sulfate and so on would have leached out during ageing, their possible presence of could not be identified with IR techniques.

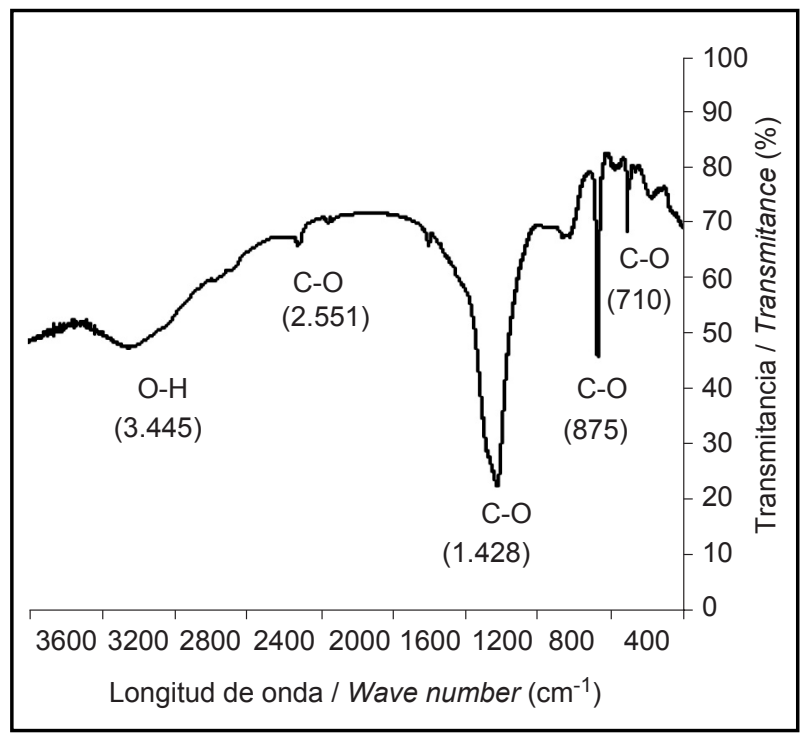

Figura 9. Espectro infrarrojo de la capa superficial. Figure 9. Infrared spectrum of the surface layer.

The appearance of this reaction product may be related to events associated with ageing:

1. The soluble components in the slag dissolve during wetting and subsequently precipitate on the surface of the particles during drying.

2. Once on the surface, atmospheric $\mathrm{CO}_{2}$ reacts with the precipitate, primarily to form calcium carbonate in the form of calcite, as discussed in the following item.

\subsubsection{Mineralogical compounds}

An XRD study was conducted on each particle size interval to determine the effect of ageing on the selected slag. Figures 10 and 11 contain the diffractograms for the two types of slag in the minimum (0-6-mm) and 


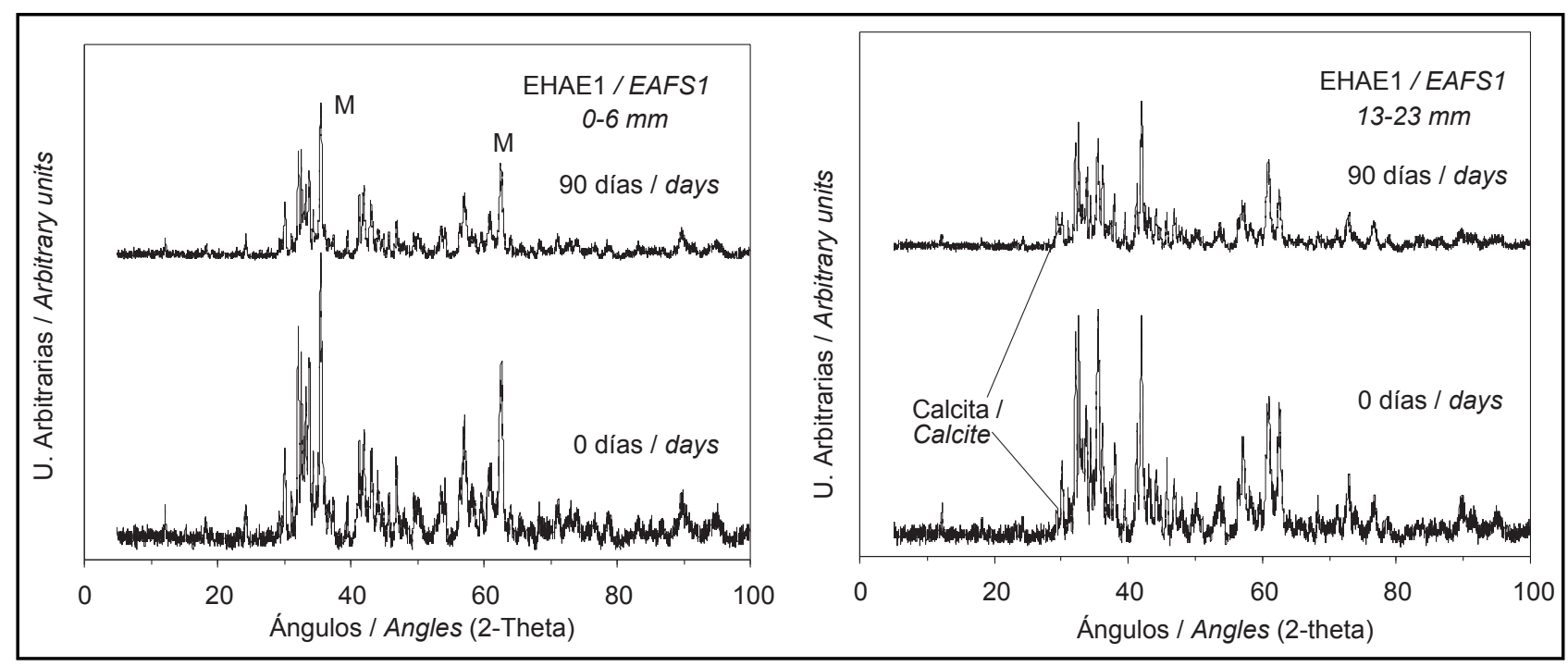

Figura 10. Evolución de los compuestos cristalinos de la escoria EHAE1 tratada.

Figure 10. Crystalline compounds in treated slag EAFS1 before and after ageing.

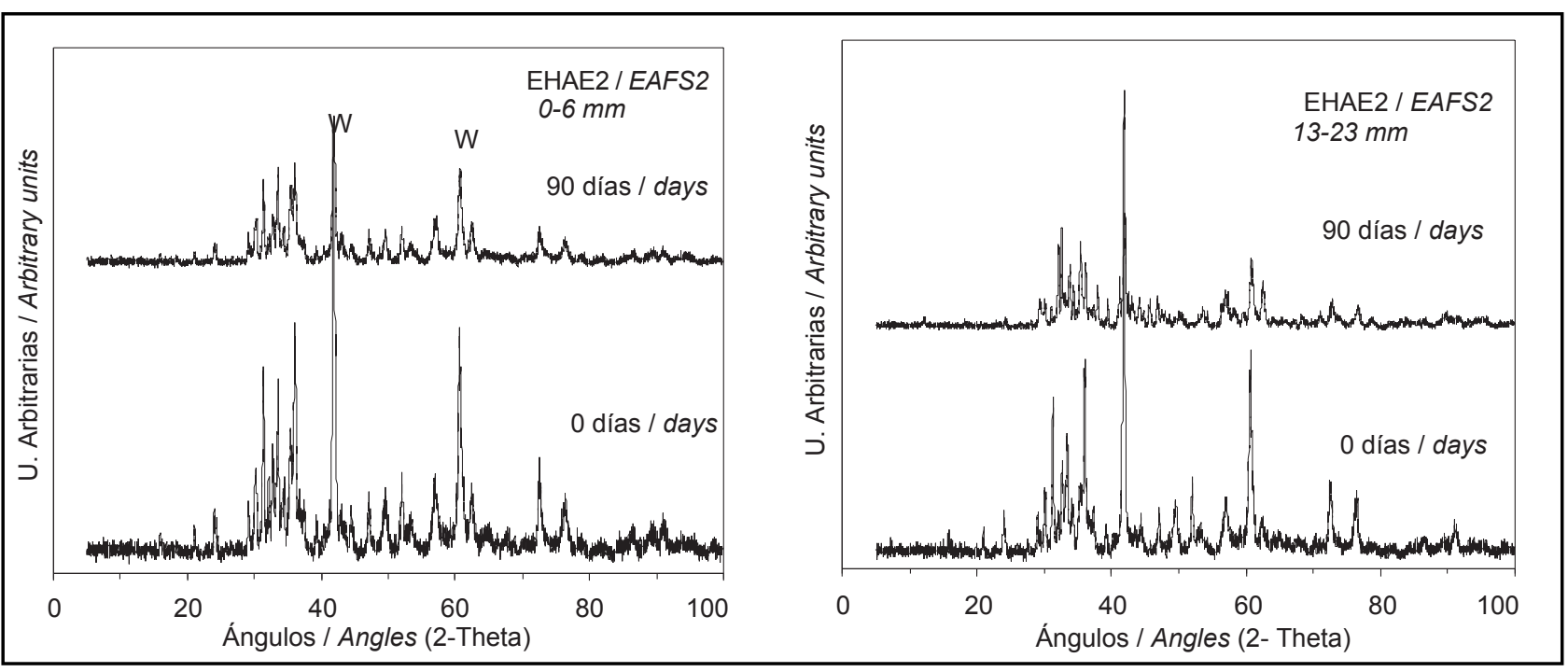

Figura 11. Evolución de los compuestos cristalinos de la escoria EHAE2 tratada.

Figure 11. Crystalline compounds in treated slag EAFS2 before and after ageing.

correspondientes, tanto de las escorias de partida ( 0 días) en los intervalos granulométricos mínimo $(0-6 \mathrm{~mm})$ y máximo $(13-23 \mathrm{~mm})$ y $23-50 \mathrm{~mm}$, como de las escorias, una vez finalizado el tratamiento de envejecimiento (90 días). De los resultados obtenidos, se observa que las escorias una vez sometidas al proceso de envejecimiento (90 días) experimentan una disminución de las intensidades de los picos de reflexión, siendo más llamativo en los compuestos cristalinos mayoritarios, como por ejemplo: magnetita (M) cuyos picos de reflexión principales están localizados a $35,422 \theta$ y $62.52 \theta$ para la escoria EHAE1 y w/plustita (W) localizados a 41,93 $2 \theta$ y $60,82 \theta$ para la escoria EHAE2; mientras que para el caso de la calcita $(29,32 \theta)$, debido a la formación de la capa blanquecina, comentada anteriormente, su intensidad se incrementa ligeramente, sobre todo en la escoria EHAE1. maximum (13-23-mm) particle size intervals, before $(0$ days) and after (90 days) ageing. According to these findings, once the slag was aged (90 days), the intensity of the reflection peaks declined, most visibly in the majority crystalline compounds such as: magnetite (M), with main peaks at $35.422 \theta$ and $62.52 \theta$ in slag EAFS1; and $w /$ plustite $(W)$, located at $41.932 \theta$ and $60.82 \theta$ in slag EAFS2. The calcite band (29.3 20), in turn, grew more intense, due to the formation of the whitish film discussed above, particularly in slag EAFS1. 
3.2.3. Cuantificación de los compuestos expansivos después del envejecimiento

La influencia del proceso de envejecimiento de las escorias analizadas en los compuestos potencialmente expansivos se recoge en la Tabla 1, donde figuran los valores analíticos a 0, 45 y 90 días de envejecimiento, respectivamente.

\subsubsection{Quantification of expansive compounds after ageing}

The effect of slag ageing on the potentially expansive compounds is shown in Table 1, which gives the analytical values for 0-, 45- and 90-day samples.

Tabla 1 / Table 1

Evolución de la cal libre, $\mathrm{MgO}$ libre y el $\mathrm{SO}_{3}$ en los procesos de envejecimiento a diferentes días de ensayo. Free lime, free $\mathrm{MgO}$ and $\mathrm{SO}_{3}$ content in slag aged for 0, 45 and 90 days.

\begin{tabular}{|c|c|c|c|}
\hline \multirow{2}{*}{$\begin{array}{c}\text { Escorias/Slag } \\
\text { Interv. granulométricos / } \\
\text { Particle size intervals }\end{array}$} & \multicolumn{3}{|c|}{ Cal libre / Free $\mathrm{CaO}(\%)$} \\
\hline & o día / days & 45 días / days & 90 días / days \\
\hline EHAE1 ${ }^{*} / 0-6 \mathrm{~mm}$ & 0.09 & 0.00 & 0.00 \\
\hline EHAE1 / 6-13 mm & 0.00 & 0.00 & 0.00 \\
\hline EHAE1 /13-23 mm & 0.06 & 0.00 & 0.00 \\
\hline EHAE2 / 0-6 mm & 0.00 & 0.00 & 0.00 \\
\hline EHAE2 / 6-13 mm & 0.06 & 0.00 & 0.00 \\
\hline EHAE2 / 13-23 mm & 0.06 & 0.00 & 0.00 \\
\hline \multirow{2}{*}{$\begin{array}{c}\text { Escorias/Slag } \\
\text { Interv. granulométricos / } \\
\text { Particle size intervals }\end{array}$} & \multicolumn{3}{|c|}{$\mathrm{SO}_{3}(\%)$} \\
\hline & O días / days & 45 días / days & 90 días / days \\
\hline EHAE1 / 0-6 mm & 0.57 & 0.30 & 0.31 \\
\hline EHAE1 / 6-13 mm & 0.35 & 0.28 & 0.30 \\
\hline EHAE1 $/ 13-23 \mathrm{~mm}$ & 0.29 & 0.20 & 0.18 \\
\hline EHAE2 / 0-6 mm & 0.13 & 0.10 & 0.09 \\
\hline EHAE2 / 6-13 mm & 0.14 & 0.05 & 0.05 \\
\hline EHAE2 / 13-23 mm & 0.15 & 0.12 & 0.10 \\
\hline \multirow{2}{*}{$\begin{array}{c}\text { Escorias /Slag } \\
\text { Interv. granulométricos / } \\
\text { Particle size intervals }\end{array}$} & \multicolumn{3}{|c|}{ Free MgO (\%) } \\
\hline & O días / days & 45 días / days & 90 días / days \\
\hline EHAE1 / 0-6 mm & 0.90 & 0.30 & 0.20 \\
\hline EHAE1 / 6-13 mm & 0.90 & 0.30 & 0.18 \\
\hline EHAE1 $/ 13-23 \mathrm{~mm}$ & 0.80 & 0.24 & 0.15 \\
\hline EHAE2 / 0-6 mm & 0.80 & 0.80 & 0.70 \\
\hline EHAE2 / 6-13 mm & 0.50 & 0.50 & 0.45 \\
\hline EHAE2 / 13-23 mm & 0.80 & 0.45 & 0.20 \\
\hline
\end{tabular}

* EHAE / EAFS.

Los resultados analíticos confirman que el proceso de envejecimiento produce una reducción en los contenidos de los compuestos expansivos presentes en las escorias (sulfatos y magnesia libre) y la total desaparición de la cal libre, debido a su alta solubilidad en agua.

Asimismo, se puede resaltar que el tratamiento de envejecimiento es principalmente efectivo durante los primeros 45 días, estabilizándose a partir de ese momento.

\subsection{Efecto de la presencia de compuestos de hierro en la estabilidad de la escoria de acería}

La estabilidad de las escorias de acería además de los compuestos analizados anteriormente depende también de la presencia de otros compuestos potencialmente oxidables
The findings confirmed that ageing reduced the expansive compound (sulfates and free magnesia) content in the slag and eliminated free lime altogether, due to the high solubility of this substance in water.

Moreover, ageing was most effective in the first 45 days, after which the values flattened.

\subsection{Effect of the presence of iron compounds on steel mill slag stability}

The stability of steel mill slag depends not only on the components analyzed above, but also on the presence of other potentially oxidizable compounds such as iron 
como los óxidos de hierro. Las escorias seleccionadas, teniendo en cuenta la composición química mostrada en la Figura 1, en función de su origen muestran contenidos en óxido de hierro total (expresado como $\mathrm{Fe}_{2} \mathrm{O}_{3}$ ) entre 40$47 \%$, favoreciendo cierta inestabilidad en aquellas.

\subsubsection{Principios básicos determinantes del comportamiento físico-químico y mecánico de las escorias}

De acuerdo con la normativa vigente EN 1744-1 (18) "la desintegración del hierro se produce por envejecimiento en una atmósfera húmeda o bajo la lluvia y más rápidamente cuando la escoria está sumergida en agua". Para este caso, se ha utilizado dicha normativa, pero en vez de 2 días de exposición, se ha realizado durante 14 días, con el objeto de acelerar la desintegración de las partículas. Posteriormente, éstas fueron examinadas tanto visualmente como a través de una lupa para detectar cualquier indicio de desintegración causado por la oxidación de los compuestos de hierro. Para este caso concreto, se seleccionaron los intervalos granulométricos superiores entre $13-23 \mathrm{~mm}$, por dos motivos: 1) por ser intervalos comúnmente utilizados en la elaboración de hormigones convencionales y, 2) por ser éstos los que presentan mayores contenidos de $\mathrm{Fe}_{2} \mathrm{O}_{3}$ (Figura 2).

\subsubsection{Resultados}

La observación por lupa binocular de las partículas de escorias después de 14 días sumergidas en agua, pone de manifiesto la ausencia de fisuras o desintegración en cada una de las partículas ensayadas, por lo que estas escorias cumplirían con este ensayo como árido de reciclado. A pesar de este buen comportamiento, se detectan alteraciones colorimétricas (amarillo-rojizo) puntuales en las superficies; especialmente, en la escoria EHAE2, debido a la oxidación de estos compuestos de hierro localizados en la misma superficie.

La forma y tamaños de estos óxidos superficiales son diferentes entre las escorias estudiadas. En la escoria EHAE1, los óxidos son muy escasos y localizados con un crecimiento perpendicular a la superficie de las partículas de escorias (Figura 12); mientras que para la escoria EHAE2 los óxidos son, visiblemente, más abundantes, con una tendencia de crecimiento paralela a dicha superficie (Figura 13). Este aumento en la oxidación superficial estaría de acuerdo no sólo con su contenido de hierro en la escoria sino también del estado de valencia a oxidar, de la estructura reticular, tipo de enlace, etc., por lo que se necesitaría nuevos estudios en esta línea de investigación. oxides. Further to the chemical composition shown in Figure 1, the total iron oxide content (expressed as $\mathrm{Fe}_{2} \mathrm{O}_{3}$ ) in the two types of slag selected ranged from 40 to $47 \%$, depending on their origin. Such high values indicate that the slag would be prone to a certain degree of instability.

\subsubsection{Basic principles that determine slag physical-chemical and mechanical behaviour}

According to European standard EN 1744-1 (18), iron disintegrates due to ageing in a damp or rainy atmosphere and more quickly if the slag is submerged in water. The method set out in that standard was used in the present study, but with an exposure time of 14 rather than 2 days to accelerate particle disintegration. The particles were subsequently examined both with the naked eye and under a microscope to detect any indication of disintegration prompted by iron compound oxidation. In this specific case, particle size intervals of over 13-23 mm were chosen, for two reasons: 1) because these are the intervals normally used to manufacture conventional concrete, and 2) because of their higher $\mathrm{Fe}_{2} \mathrm{O}_{3}$ content (Figure 2).

\subsubsection{Results}

When observed under a binocular microscope after being submerged in water for 14 days, the slag particles showed no signs of fissuring or disintegration. In this regard, then, the slag would be apt for use as recycled aggregate. Despite this good behaviour, sporadic colour alterations (yellow-reddish) were detected on particle surfaces, particularly in slag EAFS2 as a result of the oxidation of surface iron compounds.

The form and size of these surface oxides varied in the two types of slag studied. In slag EAFS1, they were sparsely distributed perpendicular to the particle surface (Figure 12), whereas in slag EAFS2 they were visibly more abundant and tended to grow parallel to the particle surface (Figure 13). Since this greater surface oxidation concurred not only with the higher iron content in this slag, but also with the valence of the ions to be oxidized and the reticular structure, type of bond and so on, further research along these lines would be required. 


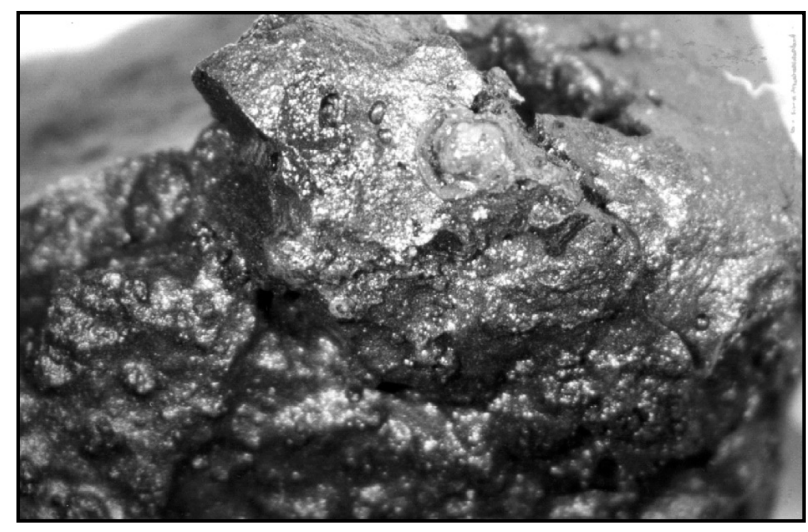

Figura 12. Aspecto de oxidación superficial de la escoria EHAE1 obtenida por lupa $(1 \times 2,5)$.

Figure 12. Surface oxidation in slag EAFS1 under $1 \times 2.5$ magnification.

\section{CONCLUSIONES}

Del estudio realizado se deducen las siguientes conclusiones:

- Químicas y cuantitativas

- Los dos tipos de escorias son similares en cuanto a la presencia de compuestos potencialmente expansivos. Las concentraciones de cal libre $(<0,1 \%)$ y cloruros $(0 \%)$ son muy bajas, o nulas; mientras que el contenido de sulfatos totales, expresados como $\mathrm{SO}_{3}$, oscilan entre 0,1 y $0,6 \%$. Dicho contenido está directamente relacionado con el intervalo granulométrico, sobre todo en la escoria EHAS1 cuyo porcentaje en sulfatos disminuía desde $0,6 \%$ en el intervalo 0-6 $\mathrm{mm}$, hasta $0,2 \%$ en el intervalo $13-23 \mathrm{~mm}$. Para el resto de los compuestos expansivos eran prácticamente constantes en todos los intervalos.

- De acuerdo con los resultados analíticos, las concentraciones de MgO libre están por debajo del $1 \%$ en peso en estas escorias de acería. Estos valores son demasiados bajos para indicar que el óxido de magnesio libre esté en forma cristalizada, que sería la responsable de su hidratación a brucita. Asimismo, resulta necesaria más investigación dirigida a establecer un método contrastado de cuantificación del contenido en magnesia libre en al escoria negra.

- Ensayos

- El ensayo acelerado ASTM D-4792 corrobora los resultados analíticos obtenidos para los compuestos expansivos. Se propone, no detectándose - por tanto- ningún tipo de inestabilidades volumétricas en dichos materiales.

- El proceso de envejecimiento para las escorias de acería, previo a su reciclado en hormigones, puede ser una manera viable para reducir o eliminar

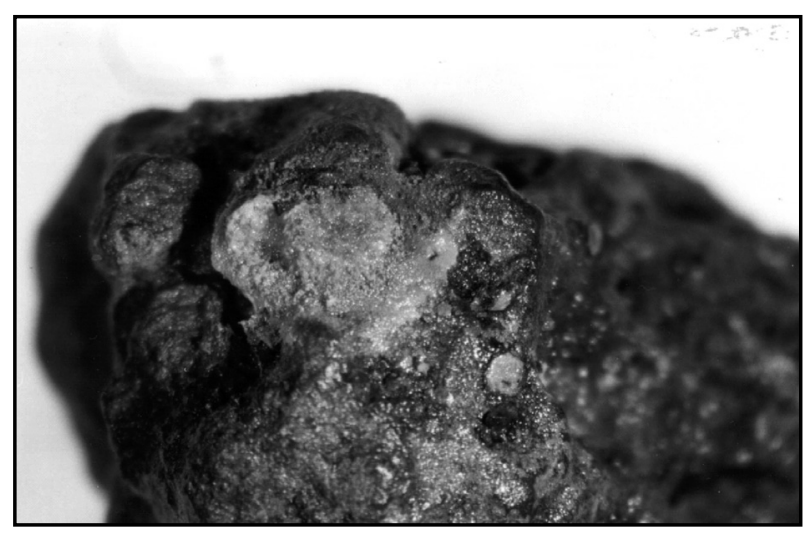

Figura 13. Aspecto de oxidación superficial de la escoria EHAE2 obtenida por lupa $(1 \times 2,5)$.

Figure 13. Surface oxidation in slag EAFS2 under $1 \times 2.5$ magnification.

\section{CONCLUSIONS}

The conclusions to be drawn from the present study are as follows:

- Chemical and quantitative:

- The presence of potentially expansive compounds was similar in the two types of slag. The free lime $(<0.1 \%)$ and chloride $(0 \%)$ concentrations were very low or nil, while the total sulfate content, expressed as $\mathrm{SO}_{3}$, ranged from 0.1 to $0.6 \%$. That content was directly related to the particle size interval, in particular in slag EAFS1, in which the percentage of sulfates declined from $0.6 \%$ in the 0-6-mm interval to $0.2 \%$ in the $13-23-\mathrm{mm}$ inter$\mathrm{val}$. The percentage content of all the other expansive compounds were practically constant in all size intervals.

- Further to the analytical results, the free $\mathrm{MgO}$ concentration was under $1 \%$ by weight in both types of steel mill slag. These values were too low to indicate whether the free magnesium oxide was in the crystal form responsible for hydration to brucite. Moreover, research would be needed to establish a reliable method for quantifying the free magnesia content in black slag.

- Tests

- The ASTM D-4792 accelerated ageing test corroborated the analytical findings for the expansive compounds, no volume instability was detected in these materials.

- Since the processes involved in steel mill slag ageing (hydration, leaching, carbonation and so on) reduce or eliminate the hazardous 
la expansividad de los compuestos peligrosos presentes en las escorias de esta naturaleza, como un resultado de diferentes procesos: hidratación, lixiviación, carbonatación, etc.

- Evolución y estabilidad cristaloquímica

- La evolución de los contenidos de los compuestos expansivos pone de manifiesto que 45 días de tratamiento son suficientes. Periodos más largos (entre 45 y 90 días) no aportan más efectividad, con los consiguientes inconvenientes técnicos y económicos para las empresas que lleven a cabo el proceso de envejecimiento.

- Las dos escorias de acerías seleccionadas presentan estabilidad de volumen con respecto a la presencia de compuestos de hierro. La plustita (FeO), compuesto cristalino mayoritario en las escorias de acerías, no produce ningún proceso de fisuración o desintegración en las partículas de escorias de acería estudiadas.

De lo anterior se deduce la aptitud de estas escorias como productos reciclados en hormigones debido a su estabilidad volumétrica y ausencia de presiones disruptivas que provoquen problemas en la calidad del hormigón. Sin embargo, cuando se detecten algunos de los compuestos potencialmente expansivos en concentraciones más importantes, se recomienda un tratamiento de envejecimiento mínimo de 45 días. components that cause expansion, this procedure may enhance the feasibility of recycling such slag in concrete.

- Crystal chemistry variations and stability

- The variation in expansive compound content showed that 45 days of treatment suffice. Longer periods (from 45 to 90 days) are no more effective, and have adverse technical and economic consequences for the companies implementing ageing procedures.

- Iron compounds induced no volume instability in either of the two types of slag selected. Plustite (FeO), the majority crystalline compound in steel mill slag, caused no cracking or disintegration in the slag studied.

The foregoing conclusions denote the aptness of this slag for use in concrete due to its volume stability and lack of any disruptive pressures that might affect concrete quality. Nonetheless, in the event of higher concentrations of any of the potentially expansive compounds, ageing treatment for a minimum of 45 days is recommended.

\section{BIBLIOGRAFÍA / BIBLIOGRAPHY}

(1) Puertas, F.; Gil-Maroto, A.; Palacios, M.; Amat, T.: "Mortero de escoria activada alcalinamente reforzados con fibra de vidrio AR: Comportamiento y propiedades", Mater. Construcc., vol. 56, no 283 (2006), pp. 79-90.

(2) Sánchez de Rojas, M. I.; Rivera, J.; Frías, M.; Marín, F.: "Use of recycled copper slag for blended cements", J. Chem. Technol. Biotecnol, vol. 83 (2008), pp. 209-217. doi:10.1002/jctb.1830

(3) De Alcaide, J. S.; Alcocel, E. G.; Puertas, F.; Lapuente, R.; Garcés, F.: "Comportamiento de morteros de escoria activada alcalinamente con adición de fibras de carbono", Mater. Construcc., vol. 57, no 288 (2007), pp. 33-48.

(4) Bonavetti, V. L.; Menéndez, G.; Donza, H. A.; Rahhal, V. F.; Irassar, E. F.: "Cementos compuestos elaborados con puzolana y escoria granulada de alto horno", Mater. Construcc., vol. 56, no 283 (2006), pp. 25-36.

(5) Motz, H.: "Production and use of air-cooled blastfurnace and steel slags", in $3^{\text {rd }}$ European Slag Conference on the Manufacturing and Processing of Iron and Steel Slags, Duisburg, Germany, vol. II (2003), pp. 7-20.

(6) Mozt, H.; Geiseler, J.: "Products of steel slags", in International Conference on the Science and Engineering of Recycling for Environmental Protection, WASCON 2000, Harrogate (UK), vol. I (2000), pp. 207-220.

(7) Reinhart, D. R.: "A review of recent studies on the sources of hazardous compounds emitted from solid waste landfills: A U.S. experience", Waste Management \& Research, no 11 (1993), pp. 257-268.

(8) San José, J. T.: "Reutilización y valorización en obra civil de escorias de horno de arco eléctrico producidas en la C.A.P.V.", Arte y Cemento, no 1891 (2000), pp. 124-126.

(9) Lind, B. B.; Falman, A. M.; Larsson, L. B.: "Environmental impact of ferrochrome slag in road construction", in International Conference on the Science and Engineering of Recycling for Environmental Protection, WASCON 2000, Harrogate (UK), vol. I (2000), pp. 247-249.

(10) Nagataki, S.; Gokce, A.; Saeki, T.: "Effect of recycled aggregate characteristics on performance parameters of recycled aggregate concrete", in $5^{\text {th }}$ International Conference on Durability of Concrete, CANMET/ACI, Barcelona, Spain, vol. I (2000), pp. 51-71.

(11) Fallman, A. M.; Kartlen, J.: "Utilisation of electric arc furnace steel slag in road construction", in Characterisation of Residues Release of Contaminants from Slag Ashes. Diss. Dpt. of Physics and Measurement Technology, Linkoping University (1997), p. 56.

(12) Sakata, K.; Ayano, T.: "Improvement of concrete with recycled aggregate", in $5^{\text {th }}$ International Conference on Durability of Concrete, CANMET/ACI, Barcelona, Spain, vol. II (2000), pp. 1089-1108. 
(13) San José, J. T.; Uría, A.: "Escorias de horno de arco eléctrico en mezclas bituminosas", Arte y Cemento, no 1905 (2001), pp. 122125.

(14) Manso, J. M.: "Fabricación de hormigón hidráulico con escorias de horno eléctrico de arco", Tesis Doctoral, Univ. de Burgos, Burgos, Spain (2001), p. 176.

(15) Losáñez, M.: "Aprovechamiento integral de escorias blancas y negras de acería eléctrica en construcción y obra civil", Tesis Doctoral, Dpto. de Ciencias de Materiales, ETSIB Univ. del País Vasco (UPV/EHU), Bilbao, Spain (2005), p. 210.

(16) Frías, M.; Sánchez de Rojas, M. I.: "Chemical assessment of the electric arc furnace as construction material: Expansive compounds", Cem. Concr. Res., vol. 34 (2004), pp. 1881-1888. doi:10.1016/j.cemconres.2004.01.029

(17) Frías, M.; Sánchez de Rojas, M. I.; Uría, A.: "Study of the instability of black slags from electric arc furnace steel industry", Mater. Construcc, vol. 52 (2002), pp. 79-83.

(18) UNE-EN-1744-1: Tests for Chemical Properties of Aggregates. Part 1: Chemical analysis (1999).

(19) Taylor, W. C.; Bogue, R. H.: "Research Reports", PCAF, January (1928), pp. 102-106.

(20) EHE-08. Instrucción Española del Hormigón Estructural, Ministerio de Fomento (ed.), Madrid, 2008, p. 722.

(21) Taylor, H. F. W.: "Cement Chemistry", Second Edition, Thomas Telford Publishing and Tomas Telford Services Ltd, England (1998), p. 437.

(22) ASTM D 4792-00, Standard Test Method for Potential Expansion of Aggregates from Hydration Reactions.

(23) ASTM D 2940-09, Standard Specifications for Grades Aggregate Material for Bases or Subbases for Highways or Airports.

(24) Vázquez, E.; Ramonich, I.; Barra Bizinotto, M.: "Durability of concretes with steel slags as aggregates", in Workshop on $R+D+I$ in Technology of Concrete Structures, - a tribute to Dr. Ravindra Gettu, Universidad Politécnica de Cataluña, 1st Edition, Barcelona, Spain (2004), pp. 23-30. 